\title{
Author Correction: PDX1LOW MAFALOW $\beta$-cells contribute to islet function and insulin release
}

\author{
Daniela Nasteska, Nicholas H. F. Fine (D), Fiona B. Ashford, Federica Cuozzo (D), Katrina Viloria, Gabrielle Smith, \\ Aisha Dahir, Peter W. J. Dawson, Yu-Chiang Lai, Aimée Bastidas-Ponce, Mostafa Bakhti (D), Guy A. Rutter (D), \\ Remi Fiancette, Rita Nano, Lorenzo Piemonti(10, Heiko Lickert (1D, Qiao Zhou, Ildem Akerman (1) \&
}

David J. Hodson (1)

Correction to: Nature Communications https://doi.org/10.1038/s41467-020-20632-z, published online 29 January 2021.

The original version of this Article contained an error in ref. 45, which was incorrectly given with the wrong author name as: Dzeja, P. et al. Mice deficient in the respiratory chain gene Cox6a 2 are protected against high-fat diet-induced obesity and insulin resistance. PLoS ONE 8, e56719 (2013). The correct form of ref. 45 is: Quintens, R. et al. Mice deficient in the respiratory chain gene Cox6a 2 are protected against high-fat diet-induced obesity and insulin resistance. PLoS ONE 8, e56719 (2013). This has been corrected in the PDF and HTML versions of the Article.

Published online: 20 July 2021

\footnotetext{
(c) Open Access This article is licensed under a Creative Commons Attribution 4.0 International License, which permits use, sharing, adaptation, distribution and reproduction in any medium or format, as long as you give appropriate credit to the original author(s) and the source, provide a link to the Creative Commons license, and indicate if changes were made. The images or other third party material in this article are included in the article's Creative Commons license, unless indicated otherwise in a credit line to the material. If material is not included in the article's Creative Commons license and your intended use is not permitted by statutory regulation or exceeds the permitted use, you will need to obtain permission directly from the copyright holder. To view a copy of this license, visit http://creativecommons.org/licenses/by/4.0/.
}

(C) The Author(s) 2021 